Vol. 23, No. 3, pp. 310 319, 2020.

\title{
Development of Glass-Ceramics and Their Application
}

\section{Sun Woog Kim ${ }^{\dagger}$, Jonghee Hwang}

Korea Institute of Ceramic Engineering and Technology, Jinju 52851, Republic of Korea

\section{결정화 유리 개발 및 응용}

\author{
김선욱 ${ }^{\dagger}$, 황종희 \\ 한국세라믹기술원
}

(Received August 27, 2020; Revised September 7, 2020; Accepted September 11, 2020)

\begin{abstract}
Glasses have become a significant part of our daily life as they are widely used in the buildings and the mobile phone displays. Among the functional glass materials, glass-ceramics are widely used in recent times and are distinguished due to their special properties. Glass-ceramics are polycrystalline solids prepared by controlled crystallization of glass. They are used as tough glass-ceramics, biocompatible glass-ceramics, and low thermal expansion glass-ceramics. Among the glass-ceramics, low thermal expansion glassceramics has received much attention due to their excellent thermal, mechanical, and optical properties and commercially used as cook top panels and telescope mirrors. In this work, we reviewed the general theory and application of glass-ceramics.
\end{abstract}

Keywords: Glass-Ceramics, Low thermal expansion, Bio-functionality, Photonics,

\section{1. 서론}

결정화 유리는 종래의 유리 제조의 개념과는 달리 유 리의 조성 및 열처리 공정을 제어하여 유리 내에 핵생성
과 결정성장을 제어함으로써 만들어진 특수한 유리로, 유리가 가지는 장점과 결정이 가지는 광학적 또는 기계 적 장점을 함께 나타낼 수 있는 다결정재료이다. 결정 화 유리가 보고되기 이전, 불안정한 유리 중에서 나타날

${ }^{\dagger}$ Corresponding Author: Sun Woog Kim skim80@kicet.re.kr 
수 있는 결정 석출은 모두 실투(devitrification)라고 하 여 문제시 되어왔으며, 유리 제조 공정에서 실투 문제를 해결하기 위한 연구가 이루어져왔다. 유리 내부에 제어 되지 않고 형성된 결정은 유리의 미관을 해치며, 강도저 하 및 표면결함의 원인으로 여겨져 왔다. ${ }^{1,2)} 1950$ 년대 중 반에 미국 코닝사의 Stookey 가 감광성 귀금속인 $\mathrm{Au}$, $\mathrm{Ag}, \mathrm{Cu}$ 등을 결정핵형성제로 첨가하여 만든 감광성 결 정화 유리(photosensitive glass-ceramics)를 발명한 이래 결정화 유리의 제조 및 응용 면에서 많은 연구가 이루어져 왔다. ${ }^{3,4)}$ 미국의 코닝사에서는 감광성 귀금속 을 이용한 감광성 결정화 유리 이외에도 $\mathrm{TiO}_{2}$ 를 결정핵 형성제로 첨가하여 강도 및 경도가 높고, 열적, 전기적 으로도 우수한 특성을 가진 $\mathrm{MgO}-\mathrm{Al}_{2} \mathrm{O}_{3}-\mathrm{SiO}_{2}$ 계 결정화 유리 및 $\mathrm{Li}_{2} \mathrm{O}-\mathrm{Al}_{2} \mathrm{O}_{3}-\mathrm{SiO}_{2}$ 계 결정화 유리를 개발하였으 며, $\mathrm{Li}_{2} \mathrm{O}-\mathrm{Al}_{2} \mathrm{O}_{3}-\mathrm{SiO}_{2}$ 계 결정화 유리가 처음으로 상품 화 되었다. $\mathrm{TiO}_{2}$ 를 첨가한 $\mathrm{Li}_{2} \mathrm{O}-\mathrm{Al}_{2} \mathrm{O}_{3}-\mathrm{SiO}_{2}$ 계 결정화 유리는 $\beta$-spodumune 고용체를 결정상으로 하는 백색 저팽창 결정화 유리로 $9 \times 10^{-7} /{ }^{\circ} \mathrm{C}$ 정도의 열팽창계수를 가진다. 결정화 유리는 유리를 재가열함으로써 석출된 결정상과 잔존 유리상과의 복합화에 의해서 새로운 특 성을 나타내고 있다. 결정화 유리의 설계에 있어서 중요 한 변수는 유리 조성, 결정화 유리상의 구성, 및 그에 따 른 결정의 미세구조 등이 있다. 열적, 전기적 특성, 내화 학성, 경도 등 많은 물리적/화학적 특성은 이러한 결정 화 유리상의 구성(결정의 종류, 결정과 유리의 상대적인 비율)에 따른다. 결정화 유리는 일반적으로 i) 유리 용융 물상태로 성형 되기 때문에 어떠한 유리성형 공정도 적 용이 가능함으로 복잡한 형상 제어가 가능하며, ii) 유리 소재 내에서 결정질이 생성됨으로 유리 내부에 기공이 거의 함유되어 있지 않으며, iii) 결정의 크기 제어를 통 하여 기계적 강도를 제어하거나, 투명성을 확보할 수 있 으며, ix) 유리 조성 설계를 통하여 석출되는 결정의 종 류를 제어함으로써 유리의 열팽창계수를 제어 할 수 있 는 특징을 가지고 있어 기존의 유리소재보다 광범위한 분야에서의 응용이 기대된다.

본 고에서는, 결정화 유리에 대한 기본적인 이론, 결 정화 유리 설계 및 공정에 따른 특성 변화, 및 결정화 유
리의 응용분야에 대해서 소개하고자 한다.

\section{2. 결정화 이론}

유리에서의 결정화는 규칙성이 적은 액체구조로부터 규칙 격자를 갖는 결정이 생성되는 과정이다. 결정 성장 은 처음에 생긴 작은 핵 위에 재료들이 석출함으로써 일 어난다. 따라서 결정화 과정은 핵생성과 결정성장으로 구분된다. 결정화 유리의 주요 결정상은 유리의 기초 조 성에 의해 거의 결정되나 핵생성은 유리의 분상을 촉진 하고, 불균질 결정핵생성을 위한 이종결정 표면을 제공 하는 핵생성 촉진제의 유무 및 양에 의해 영향을 많이 받는다. 결정화 과정은 핵생성속도와 결정성장속도의 2 가지 인자에 의해 지배된다. 유리를 냉각시키면 점도가 갑자기 커져 용융체에서는 핵생성과 결정성장속도에서 최대점이 나타나며 그 이유는 최대점 이하의 더 낮은 온 도에서의 높은 점도는 핵생성과 결정 성장에 필요한 원 자 재배열과 확산 과정을 방해하기 때문이다. 따라서 점 성 용융체의 핵생성속도와 결정성장속도에 대한 곡선은 Fig. 1(a)와 같은 모양을 나타낸다.

결정화 유리 제조를 위한 열처리 공정은 Fig. 1 (b) 와 같다. 결정화를 위한 열처리 공정의 첫 단계는 핵생 성 공정으로 실온에서 핵생성온도까지 유리를 가열하는 과정이다. 보통 최적 핵생성온도는 점도가 $10^{11} \sim 10^{12}$ poise에 해당되는 온도 범위 내에 있으며 통상적으로 최 적 핵생성온도를 유리 전이온도 $(\mathrm{Tg})$ 와 이보다 $50^{\circ} \mathrm{C}$ 높 은 온도 사이에서 정해 핵생성을 위한 열처리를 진행한 다. 유리가 핵생성 온도에서 유지되어야 하는 시간은 보 통 0.5 2 시간 정도 이다.

열처리 공정의 두 번째 단계는 결정을 성장시키는 단 계로 유리를 제어된 가열속도에서 충분히 느리게 온도 를 높이면 유리 기구가 변형되지 않고 내부에서 결정 성 장이 일어난다. 결정 성장 시간은 적어도 1 시간 동안 유 지시켜야 하나 결정화 유리 중에서 원하는 결정도를 얻 기 위해서는 더 오랜 시간 유지시킬 수도 있다. 유지시 간이 경과한 후에는 결정화 유리를 실온까지 냉각시켜 준다. ${ }^{3}$ 잘 제어된 내부 결정화는 미세하게 잘 분산되게 


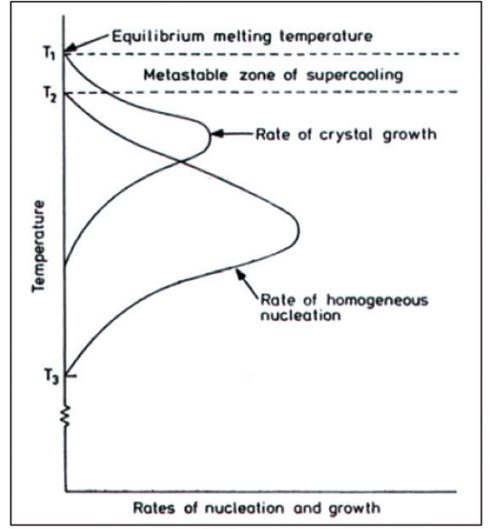

(a) 핵생성 및 결정화 구간

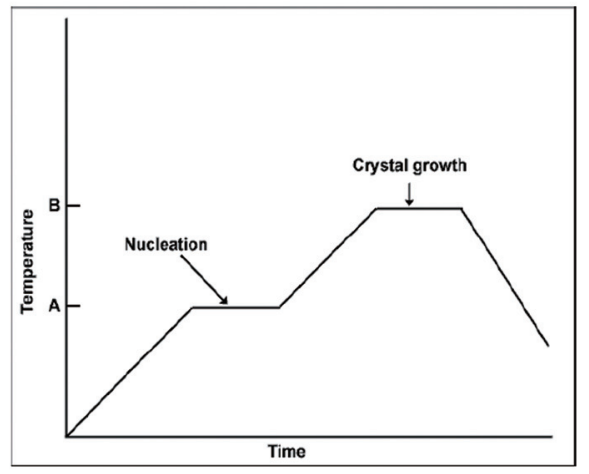

(b) 결정화 열처리 공정

Fig. 1. 핵생성 및 결정화 구간과 결정화를 위한 열처리 공정

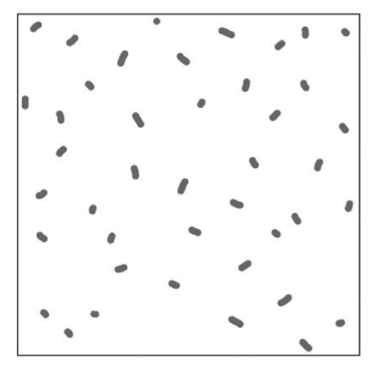

(a)

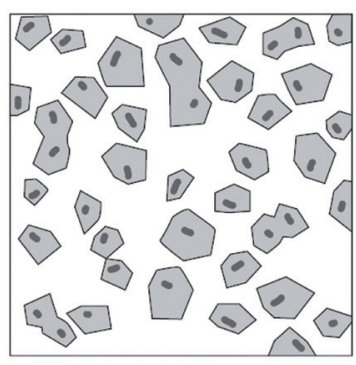

(b)

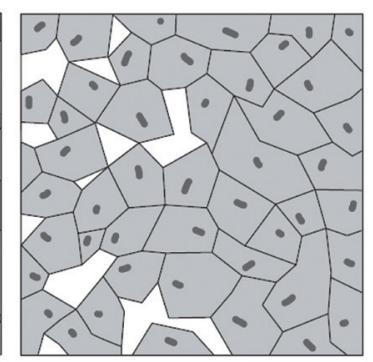

(c)

Fig. 2. 결정화 유리의 결정화 과정 (a) 핵생성 (b) 핵중심의 결정성장 (c) 결정화 유리의 미세구조

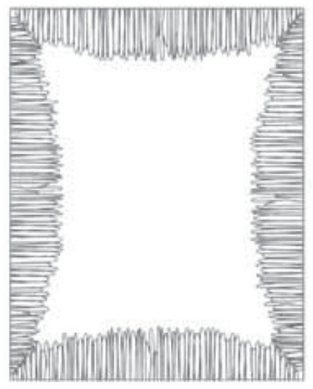

a)

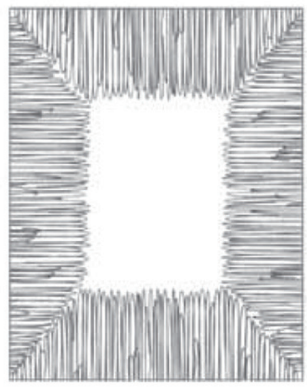

b)

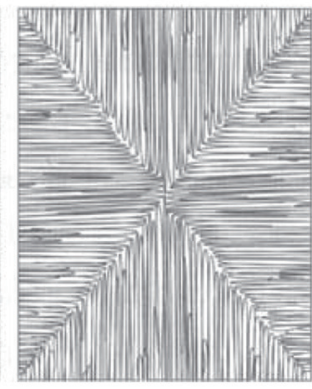

c)

Fig. 3. 내부 결정화를 동반하지 않은 유리의 결정화

석출되는 결정입자들을 발달시킬 수 있는 효율적인 핵 생성에 의존한다. 결정화 유리 공정은 Fig. 2 에서 설명 된 바와 같이 기본적으로는 잘 제어된 열처리 공정으로 볼 수 있다. 반면 잘 제어된 내부 결정화가 일어나지 않 는 경우에는 Fig. 3과 같이 실투(devitrification) 가 에 너지 준위가 낮은 표면에서부터 진행되어 내부로 확산
되어 갈 수 있다. ${ }^{2}$

\section{3. 저팽창 결정화 유리}

\section{1 저팽창 결정화 유리 종류 및 특성}

저팽창 결정화 유리는 일반적으로 열팽창계수의 절대 
치가 약 $30 \times 10^{-7} /{ }^{\circ} \mathrm{C}$ 이하인 유리를 통칭하는 것으로, 대표적인 저열팽창 결정화 유리는 $\mathrm{TiO}_{2}$ 를 첨가한 $\mathrm{Li}_{2} \mathrm{O}-$ $\mathrm{Al}_{2} \mathrm{O}_{3}-\mathrm{SiO}_{2}$ 계 결정화유리이다. 저열팽창 결정화 유리 는 투명 결정화 유리, 백색 저팽창 결정화 유리 및 열 선(적외선)을 투과하는 흑색 저팽창 결정화 유리 3종류 가 있다. 이들은 저팽창 결정화 유리 조성 및 유리 내부 에 석출되는 $\mathrm{Li}_{2} \mathrm{O}-\mathrm{Al}_{2} \mathrm{O}_{3}-\mathrm{SiO}_{2}$ 계 결정의 종류, 크기 및 결정량을 제어함에 따라 그 형태가 변화되며, Fig. 4에 나타내는 열처리 공정도로 설명할 수 있다. ${ }^{5,6)}$ Fig. 4에 나타낸 것 과 같이, $\mathrm{TiO}_{2}$ 를 첨가한 $\mathrm{Li}_{2} \mathrm{O}-\mathrm{Al}_{2} \mathrm{O}_{3}-\mathrm{SiO}_{2}$ 계 결정화 유리 조성의 원료를 약 $1700{ }^{\circ} \mathrm{C}$ 정도에서 용 융 후 상온까지 냉각시켜 제조한 유리를 $750 \sim 800^{\circ} \mathrm{C}$ 에 서 핵형성 처리한 후, 약 $850 \sim 950{ }^{\circ} \mathrm{C}$ 의 온도영역에 서 열처리함으로써, 형성된 결정핵 위에 $\beta$-quartz 고용 체 결정 $\left(\mathrm{Li}_{2} \mathrm{O} \cdot \mathrm{Al}_{2} \mathrm{O}_{3} \cdot \mathrm{nSiO} \mathrm{Si}_{2}, \mathrm{n} \geq 2\right)$ 이 약 $50 \mathrm{~nm}$ 크기 로 성장을 하고, 결정질과 유리질의 비율이 70:30 wt\% 일 때 투명 저팽창 결정화 유리가 만들어진다. 그리고 열처리 온도, 즉 핵성장 온도를 약 $1100 ~ 1200^{\circ} \mathrm{C}$ 의 온 도대에서 결정 성장 처리를 하면 $\beta$-spodumune 고용 체 결정 $\left(\mathrm{Li}_{2} \mathrm{O} \cdot \mathrm{Al}_{2} \mathrm{O}_{3} \cdot \mathrm{nSiO}, \mathrm{n} \geq 4\right)$ 이 약 $1 \mu \mathrm{m}$ 의 크기 로 되어 약 $90 \mathrm{wt} \%$ 의 결정상으로 석출되므로 백색 저팽 창 결정화 유리가 된다. ${ }^{7}$ 그리고 흑색 저팽창 결정화 유 리는, $\mathrm{Li}_{2} \mathrm{O}-\mathrm{Al}_{2} \mathrm{O}_{3}-\mathrm{SiO}_{2}$ 계 결정화 유리 조성에 결정 형 성제 $\mathrm{TiO}_{2}$ 와 착색제로 $\mathrm{V}_{2} \mathrm{O}_{5}$ 를 첨가하여 제조한다. 고 온용융법으로 제조한 유리를 $750{ }^{\circ} \mathrm{C}$ 에서 핵을 형성시

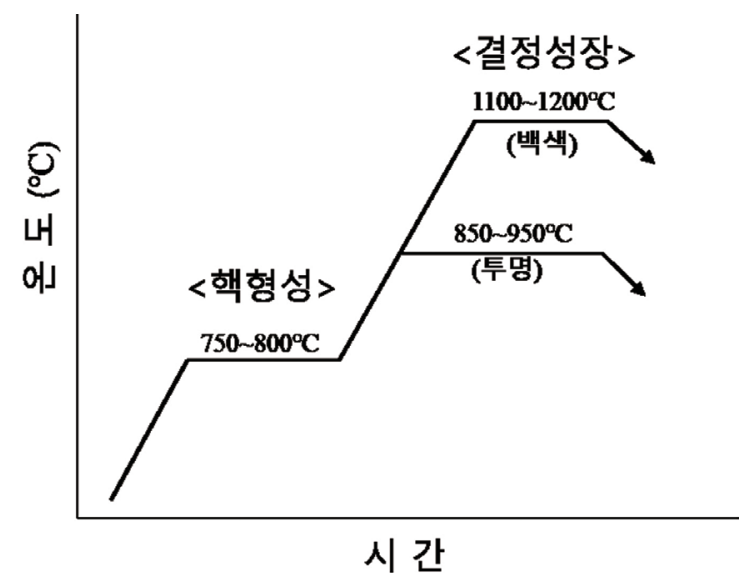

Fig. 4. 저팽창 결정화 유리 제작 열처리 공정도
키고, $850{ }^{\circ} \mathrm{C}$ 에서 핵을 성장시키면 약 $50 \mathrm{~nm}$ 크기의 $\beta$ -quartz 고용체 결정 $\left(\mathrm{Li}_{2} \mathrm{O} \cdot \mathrm{Al}_{2} \mathrm{O}_{3} \cdot \mathrm{nSiO}_{2}, \mathrm{n} \geq 2\right)$ 이 약 $70 \%$ 형성되고, V과 $\mathrm{Ti}$ 에 의해서 착색되어 흑색을 띠게 된다.

저팽창 결정화 유리는 열적/기계적 특성이 우수하 며, 광학적 특성이 우수하여 광범위한 분야에서의 응용 이 기대되고 있다. 상기 기술한 것과 같이 $\mathrm{TiO}_{2}$ 를 첨가 한 $\mathrm{Li}_{2} \mathrm{O}-\mathrm{Al}_{2} \mathrm{O}_{3}-\mathrm{SiO}_{2}$ 계 저팽장 결정화 유리는 투명, 백 색, 흑색을 나타내는 3 종류로 분류될 수 있으며, 이들의 열팽창계수는 약 $-4 \times 10^{-7} /{ }^{\circ} \mathrm{C}, 12 \times 10^{-7} /{ }^{\circ} \mathrm{C}$, 및 0.2 $\times 10^{-7} /{ }^{\circ} \mathrm{C}$ 이다. ${ }^{6)}$ 저팽창 결정화 유리의 낮은 열팽창계 수는 유리 내부에 형성된 결정상의 결정 구조로 설명이 가능하다. 투명 저팽창 결정화 유리의 내부에 형성된 $\beta$ -quartz 고용체 결정은 6 개의 $(\mathrm{Si}, \mathrm{Al}) \mathrm{O}_{4}$ 사면체로 구 성된 사슬 구조가 c축 방향으로 형성되어 있으며, 빈 공 간에 $\mathrm{Li}$ 이온이 위치하는 결정구조를 가지고 있다. 온도 가 증가함에 따라 결정구조 내에서 $\mathrm{Li}$ 이온이 4 배위 자 리에서 6 배위 자리로 이동을 하게 되며, $(\mathrm{Si}, \mathrm{Al}) \mathrm{O}_{4}$ 사 면체에 의해서 구성된 골격 구조가 $\mathrm{a}, \mathrm{b}$ 축 방향으로 다 소 확대, $\mathrm{c}$ 축 방향으로 수축하게 된다. 그 결과, 결정의 단위 격자는 크게 수축하게 되고, $\beta$-quartz 고용체 결 정은 마이너스의 팽창 특성을 가지게 된다. 투명 저팽창 결정화 유리는 $70 \%$ 의 $\beta$-quartz 고용체 결정상과 $30 \%$ 의 유리지상으로 구성이 되어있으며, 결정상의 마이너 스 팽창 특성과 유리질의 팽창 특성이 서로 상쇄되어 0 에 가까운 열팽창특성을 가지게 된다. 또한, 백색 저팽 창 결정화 유리에서 형성되는 $\beta$-spodumune 고용체 결 정은 정방정계 결정 구조를 가지고 있으며, 격자 내부의 공극 자리에 $\mathrm{Li}$ 이온이 위치하고 있다. ${ }^{9)} \beta$-spodumune 고용체 결정도 $\beta$-quartz 고용체 결정과 동일하게 온도 가 증가함에 따라 $\mathrm{Li}$ 이온이 4 배위 자리에서 6 배위 자 리로 이동하게 된다. 하지만 그 비율이 아주 작기 때문 에 $\mathrm{c}$ 축 방향으로 팽창, $\mathrm{a}$ 축 방향으로 수축하더라도 전 체적으로는 약 $9 \times 10^{-7} /{ }^{\circ} \mathrm{C}$ 의 열팽창계수를 가진다. $\beta$ -spodumune 고용체 결정 $90 \mathrm{wt} \%$ 와 $10 \mathrm{wt} \%$ 의 유리 질로 구성된 백색 저팽창 결정화 유리는 $\beta$-spodumune 고용체 결정의 열팽창계수와 유리질의 열팽창계수가 복 


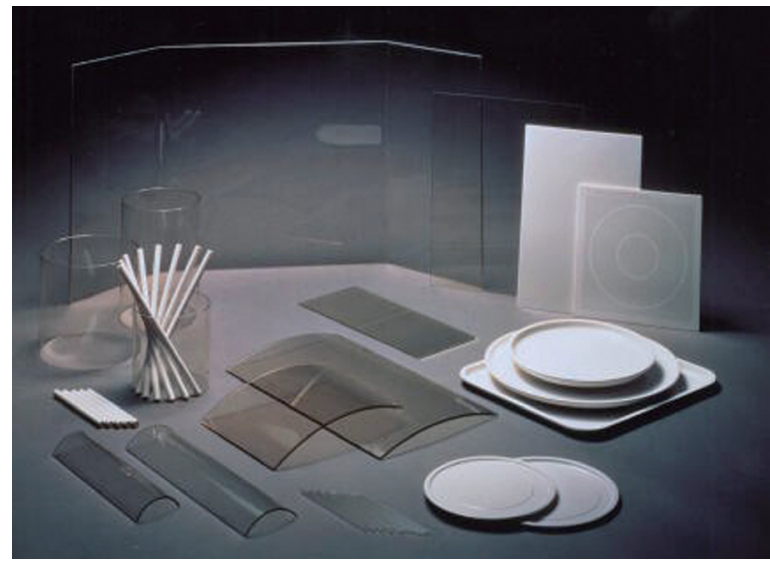

Fig. 5. 제로 팽창 결정화유리

합화 되어 약 $12 \times 10^{-7} /{ }^{\circ} \mathrm{C}$ 정도의 열팽창계수를 가진다. 그리고 저팽장 결정화 유리의 열충격 강도는 $\Delta \mathrm{T}=600$ $\sim 800{ }^{\circ} \mathrm{C}$ 정도로 상용 중인 내열 유리 $\left(\Delta \mathrm{T}=180{ }^{\circ} \mathrm{C}\right)$ 와 비교하여 아주 높은 값을 가진다. 때문에 투명, 흑색 저팽창 결정화 유리는 $800{ }^{\circ} \mathrm{C}$ 로 가열 후, $0{ }^{\circ} \mathrm{C}$ 로 급냉 을 시키더라도 부서지거나 변형이 일어나지 않으며, 사 용 가능 온도가 약 $750{ }^{\circ} \mathrm{C}$ 정도로 내열 유리 $230{ }^{\circ} \mathrm{C}$ 보다 아주 높은 수준이다. 이러한 열적 특성 때문에 저팽창 결정화 유리는 미사일의 노즈콘(nose cone)으로 용도 가 제안되기도 하였다. Fig. 5에 나타내는 것과 같이 투 명 저팽창 유리는 유리 소재 본연의 특성인 투명성까지 가지고 있어 그 활용범위가 아주 높다. 투명 저팽창 결 정화 유리는 석출된 결정의 크기가 약 $50 \mathrm{~nm}$ 이하로 가 시광의 파장보다 작으며, 결정상의 석출 비율이 낮아 광 산란이 일어나지 않기 때문에 가시광영역에서부터 적외 선 영역까지 광범위한 영역에서 높은 광투과율 나타낸 다. 반면, 흑색 저팽창 결정화 유리의 경우 유리 내부에 서 석출되는 결정의 크기나 종류가 동일 함에도 불구하 고 흑색을 나타내는 이유는 유리질 내부에 함축된 $\mathrm{Ti}$ 와 $\mathrm{V}$ 이온에 의해 가시광영역의 빛이 흡수되어서 반사광으 로 흑색을 나타내게 된다. 하지만, 흑색의 저팽창 결정 화 유리도 유리 내부에 석출된 결정의 크기가 작기 때문 에 Ti와 V이온의 광흡수밴드가 없는 적외선 영역에서는 투명 결정화 유리와 동일하게 아주 높은 광투과율 나타 낸다. 이러한 특성으로 저팽창 결정화 유리는 고온영역
에서의 작업을 관찰하기위한 윈도우 소재로 많이 이용 이 되고 있다. 저팽창 결정화 유리는 열적, 광학적 특성 이외에도 결정이 약 $70 \mathrm{~nm}$ 정도로 미세함과 동시에 극 저 열팽창 특성, 높은 영율을 가지므로 원자 레벨의 평 활 연마를 하더라도 가공에서 생기는 결정면 변화, 변 형, 스크래치 등의 문제를 최소한으로 할 수 있어 최근 의 초정밀 연마에 대응이 가능하다. 또한 일반 유리에 비해 높은 기계적 강도 값을 갖는다.

\section{2 저팽창성 결정화 유리 용도}

저팽창성 투명 결정화 유리는 특수 성분 글라스를 용 해하고, 열처리를 함으로써 글라스 중에 미세한 결정을 다수 석출 시킴으로 얻어지는 치밀한 미세결정입자의 복 합체이다. 이들 결정 생성에 의해 기계적 강도가 향상됨 과 동시에 특수 결정 형성에 의해 초저팽창 특성 구현이 가능한 재료이다. 결정 입자의 크기 조절을 통해 높은 투광성을 얻을 수 있는 재료로, 특히 일반 글라스에서 투과율이 낮은 군사적 목적으로 많이 사용되는 적외선 영역의 투과율이 높은 재료이다. 따라서 극한 환경 하에 서 군사용 뿐만 아니라 특수 용도의 민수용으로 활용이 기대되는 재료이다. 구체적으로 적용 가능한 민수용 용 도로는 반도체 제조 장치용 소재, 정밀광학소재, 광학 부품 소재, 대형 미러 소재, 항공 장치용 소재, 정밀기기 부품소재, 내열 가전용 소재, 건축용 소재 등이다.

투명 저팽창 결정화 유리는 높은 열충격강도와 우수 한 투광성을 가지고 있어, 고온영역에서의 작업환경을 관찰할 수 있기 때문에 특정방화설비(60분 단염성능)와 일반방화설비(20분 단염성능) 2종류의 방화유리로서 건 축자재로 사용되고 있다. 그리고 최근 건축물에서는 방 화 성능에 안전 성능을 부여한 방화유리에 대한 요구가 높아지고 있어, 이에 대응하기 위하여, 결정화 유리를 $\mathrm{THV}$ 중간 막으로 합친 방화 유리가 개발되어 보급되고 있다. Fig. 6에 방화문용 제로 팽창 결정화 유리를 나타 내었다. 최근, 건축물이 대형화 됨에 따라 방화창의 개 구부 면적이 커지게 되고 이로 인하여 화재 시 대피 경 로의 복사열을 감소시키는 것은 인명구조에 있어서 아 주 중요한 부분이다. 복사열 감소를 위하여, 방화 결정 


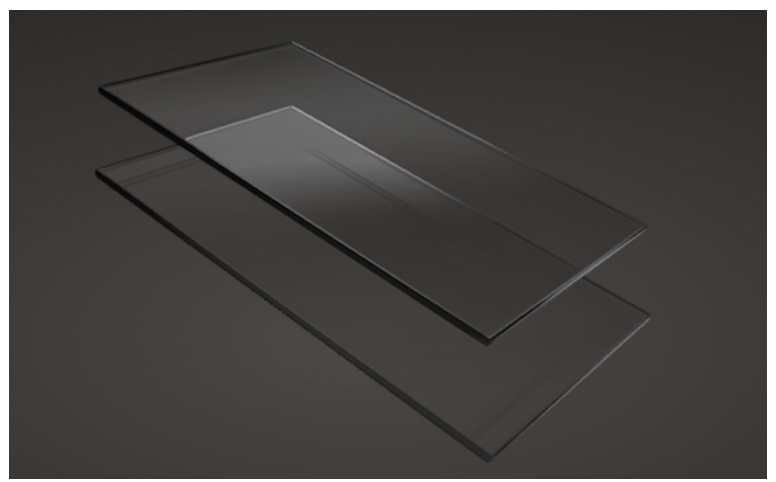

Fig. 6. 방화문용 결정화유리 (Fire Lite)

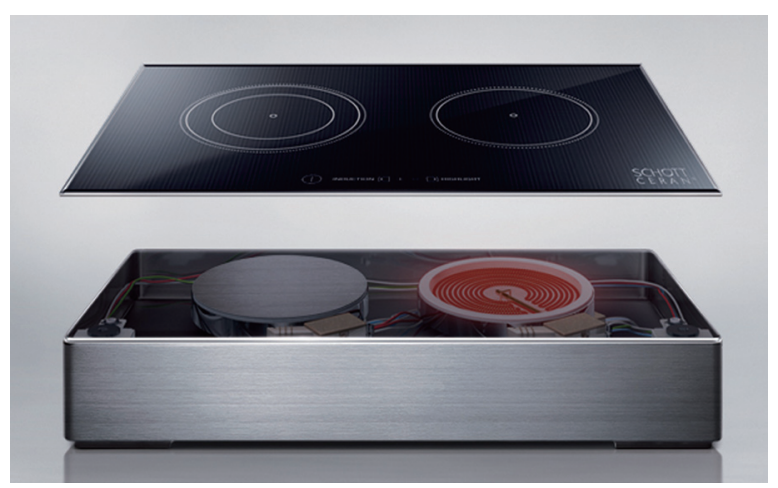

Fig. 7. Cooktop용 결정화유리-Seran (Schott)

화 유리의 표면에 투명한 열선반사막을 코팅한 방화 단 열 유리가 개발되었으며, 이 유리 소재의 방화 및 단열 특성과 함께 투명한 광학적특성으로 인하여 건물의 화 재 시 피난에 필요한 30 분 이상의 시간 동안의 투시가 확보되었다. 또한, 투명 저팽창 결정화유리의 높은 열충 격특성은 방화 유리 등의 건축자재 이외에도 가정용품 에도 많이 사용이 되고 있다. 상기 3.1에서 기술한 것과 같이 투명 저팽창 결정화 유리는 $750{ }^{\circ} \mathrm{C}$ 에서 사용이 가 능하며, $800{ }^{\circ} \mathrm{C}$ 까지 가열 후 $0{ }^{\circ} \mathrm{C}$ 로 급냉각을 시켜도 파 괴나 형상의 변화가 일어나지 않는다. 이러한 특성을 이 용한 대표적인 가정용품 소재는 짧은 시간에 가열과 냉 각이 이루어지는 전자레인지에 사용되는 쟁반 및 윈도 우 소재이다. 또한, 최근에는 결정화 유리의 높은 기계 적 특성을 함께 이용하여, 인덕션 탑플레이트(induction top plate) 소재로도 사용이 되고있다. Fig. 7에 독일의 Schott사는 저팽창성 결정화 유리 Seran을 적용하여 인

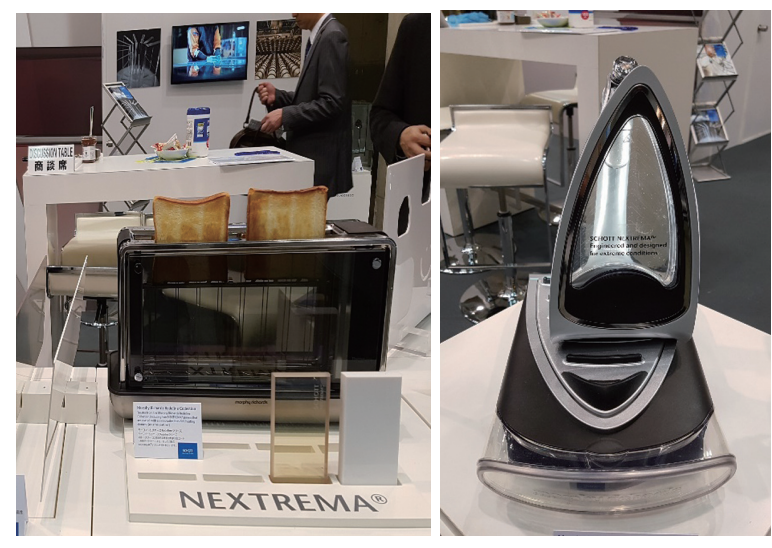

Fig. 8. 저항막 코팅방식 발열 결정화유리 적용 토스터와 전기다리미 (Schott)

덕션 쿡탑(induction cooktop) 이미지를 나타내었다. 인덕션의 경우 사용하지 않을 때 내부에 설치된 히터나 배선을 가려주고, 사용시에는 열선이 효과적으로 투과 시킬 수 있는 흑색 저팽창 결정화 유리가 주로 사용되고 있다. 또한, 최근 Fig. 8에 보인 바와같이 high-end용 투명 토스트기, 투명 전기다리미 등 투명발열체용 기판 소재로도 활용되고 있다. 저팽창 결정화 유리는 우수한 열적/광학적/기계적 특성으로 인하여 방화 유리, 가열 용 가전용품 이외에도 프로젝터의 반사경, 광파이브 부 재, 반도체/디스플레이용 부재 등 광범위한 분야에서 사 용이 되고 있다.

\section{4. 생체기능재료용 결정화 유리}

최근 15 년간 고유의 강도 및 가공성을 가진 마이카 (mica)계 결정화 유리는 비약적으로 성장하고 있는 생 체기능재료의 분야를 확대 시켜왔다. 인공 골절용 생 체기능재료는 생체 적합성 뿐만 아니라 높은 생체 활성 을 제공한다. 또한, 마이카, 마이카/불산아파타이트의 결정화 유리는 단단하게 가공이 가능하며 생체적합성 이 우수하여 인공골재로서 많이 연구되고 있다. ${ }^{10,11)}$ 마 이카를 기본 소재로 하는 인공 골절 재료 뿐만 아니라 결정화 유리는 인공치아 분야에서 많이 사용이 되고 있 다. ${ }^{12,13)}$ 그리고 최근에는 높은 강도와 우수한 화학적 내 구성을 가진 $\mathrm{SiO}_{2}-\mathrm{Li}_{2} \mathrm{O}-\mathrm{K}_{2} \mathrm{O}-\mathrm{ZnO}-\mathrm{P}_{2} \mathrm{O}_{5}$ 계 유리 내 
에 핵생성 시킨 리튬 디실리케이트(lithium disilicate) 결정화 유리는 치과 분야의 생체기능재료로 많이 사용 이 되고 있다. ${ }^{14)}$ 치과 분야의 생체기능재료로는 전체 를 세라믹으로 제작하는 방법을 고안하기에 이르러, 강 화 주성분 및 공정에 따라 고강도 알루미나 세라믹, 팽 창성 마그네시아 세라믹, 주조 용 결정화 유리, 고온 가 압 결정화 유리 및 고강도 유리 침투 알루미나 세라믹 등 소재의 물성과 사용의 편의성을 향상시키는 방향으 로 다양하게 사용되고 있다. 특히, 최근에는 루사이트 (leucite) 기반의 고열팽창 $\mathrm{K}\left[\mathrm{AlSi}_{2} \mathrm{O}_{6}\right]$ aluminosilicate 결정화 유리 소재가 높은 생체친화성을 가지고 있으 며, 화학적, 물리적, 및 기계적으로 우수하 뿐만 아니라 computer aided manufacturing (CAM; 컴퓨터 지원 생산)으로 가공도 용이하여 많은 주목을 받고 있다. ${ }^{12,13)}$ 루사이트(leucite) 결정화 유리는 모 글라스(base glass) 인 $\mathrm{K}_{2} \mathrm{O}-\mathrm{Al}_{2} \mathrm{O}_{3}-\mathrm{SiO}_{2}$ 시스템 주조성과 핵생성제 및 결 정화제 등의 첨가제로 구성되며, 모글라스의 핵생성 (nucleation)과 결정화(crystallization) 등의 조절을 통해 제조된다. Computer aided design/Computer aided manufacturing (CAD/CAM; 컴퓨터 지원 설 계/컴퓨터 지원생산)이 가능한 치과용 결정화 유리로 는 리튬 디실리케이트 기반의 결정화 유리가 있다. 리 튬 디실리케이트 기반의 결정화 유리는 루사이트 결정 화 유리보다 높은 강도(strength)와 파괴인성(fracture toughness)을 가진다. 리튬 디실리케이트 결정화 유리 는 $\mathrm{SiO}_{2}-\mathrm{Li}_{2} \mathrm{O}-\mathrm{K}_{2} \mathrm{O}-\mathrm{ZnO}-\mathrm{P}_{2} \mathrm{O}_{5}-\mathrm{Al}_{2} \mathrm{O}_{3}$ 시스템에서 최 적의 핵생성과 결정화의 조절을 통해 루사이트 결정화 보다 높은 결정화도(crystal content, 약 $70 \mathrm{vol} \%$ 이 상)를 가지며, 높은 결정화도와 결정 결합율(degree of interlocking crystals)에 의해 약 $300 \mathrm{MPa}$ 이상의 강 도와 $2.0 \mathrm{MPa} \cdot \mathrm{m}^{1 / 2}$ 이상의 파괴인성을 가진다. 결정화 가 완료된 리튬 디실리케이트 형태의 결정화 유리는 가 공유리로 사용하기에는 너무 단단하여 다이아몬드 툴 (diamond tool)을 가진 CAD/CAM으로는 가공하기가 어려운 것으로 알려져 있다. 따라서, 이를 해결하기 위 해서 $\mathrm{SiO}_{2}-\mathrm{Li}_{2} \mathrm{O}-\mathrm{K}_{2} \mathrm{O}-\mathrm{P}_{2} \mathrm{O}_{5}-\mathrm{Al}_{2} \mathrm{O}_{3}-\mathrm{ZrO}_{2}$ 시스템의 열 처리 공정(heat treatment process)을 조절하여 적절
한 기계적인 물성을 가진 리튬 메타실리케이트(lithium metasilicate)라는 중간상(intermediate phase)이 생성 하게 되는데, 이 재료를 block 형태로 $\mathrm{CAM}$ (milling) 가 공에 사용한다. 중간상인 리튬 메타실리케이트는 푸른 빛의 색상과 매우 낮은 화학적, 물리적 내구성을 가지 게 되지만, $800^{\circ} \mathrm{C}$ 이상의 결정화 공정(crystallization process)을 통해 치아 색상을 가진 단단한 리튬 디실리 케이트로 전환되며, 고체상태반응(solid state reaction) 으로 치아와 유사한 광학적 성질과 화학적 내구성이 증 가하게 된다.

\section{Photonics융 결정화 유리}

결정화 유리 재료는 유리 재료가 가지지 못하는 광학 적/열적 성질을 가지고 있으며, 유리와 동일하게 성형이 가능하고 성형 후 결정화가 가능하기 때문에 유리소재 로는 사용하지 못하는 photonics용 소재로의 적용가능 성이 많은 주목을 받고있다.

\section{1 (-)열팽창 계수를 갖는 기판소재}

결정화 유리가 가지는 유용성이 높은 특성 중 하나가 (-)열팽창 계수를 가지는 것이다. 이러한 (-)열팽창 특 성으로 인하여 결정화 유리는 다양한 광부품에 응용이 가능하다. 특히, 광범위한 영역에서 사용이 되고 있는 광센서(Fiber Bragg Grating; FBG)에서 온도 영향을 저감 시키는데 중요한 역할을 한다. ${ }^{15)} \beta$-eucryptite 고 용체 결정을 기반으로 하는 lithiumaluminosilicate계 의 (-)열팽창계수를 가진 결정화 유리가 개발되었다. ${ }^{16)}$ $\beta$-eucryptite 고용체 결정은 $\beta$-quartz와 유사한 결정 구조를 가지고 있으나, 아주 큰 열팽창이방성을 가지기 때문에 $-40{ }^{\circ} \mathrm{C}$ 에서 $85{ }^{\circ} \mathrm{C}$ 까지의 온도범위에서 -5.0 부 터 $-8.0 \mathrm{ppm} /{ }^{\circ} \mathrm{C}$ 정도의 아주 큰 (-)열평창계수와 마이 크로크랙(microcrack)을 가지는 재료가 얻어진다. 또 한, $\beta$-eucryptite 고용체 결정화 유리는, $\mathrm{FBG}$ 의 온도 에 의한 파장변동의 보상을 할 수 있기 때문에 이상적인 기판유리로 주목을 받고 있다. 


\section{2 파이브 증폭기}

광증폭기와 에리저는 광통신 시스템의 기본적인 능동 소자이다. 대부분의 현행 광증폭기는 $\mathrm{Er}$ 이온을 첨가한 실리케이트(silicate) 유리를 기본조성으로 하지만, 희토 류 이온이 응집하는 것을 억제하기 위하여, 실리케이트 유리에 $\mathrm{Al}_{2} \mathrm{O}_{3}$ 를 소량 첨가하고있다. 이 조성의 파이브 증폭기는 일반적으로 $\mathrm{C}$ 밴드라고 하는 약 $1523 \sim 1565$ $\mathrm{nm}$ 의 파장영역에서 유효하다.

불화물의 결정과 유리는 포논에너지(phonon energy) 가 낮고, 근적외선 영역 광을 효과적으로 투과하기때문 에 광학적 활성물질인 희토류 이온의 모체결정으로 적 합하다. 하지만, 불화물계 유리는 산화물계 유리와 비교 하여 화학적 안정성과 기계적 안정성이 떨어지기 때문 에 유리를 제작하기가 어렵다. 그래서 이러한 문제점을 해결하기 위하여 silicate 유리에 불화물결정을 분산시 킨 투명 oxyfluoride 결정화 유리가 보고되었으며, 이는 불안정한 희토류 첨가 불화물계 유리의 발광 효율을 효 과적으로 증가시키는 것이 보고 되었다. ${ }^{17)}$ 또한, $\mathrm{Y}$ 이온 과 $\mathrm{Er}$ 이온을 함께 첨가한 카드늄, 납 불화물계 결정을 석출 시킨 aluminosilicate계 결정화 유리가 녹-청색광 조사에 의해서 up-conversion과 down-conversion 의 발광특성을 나타내는 것이 보고되었다. ${ }^{18)}$ 이외에도 aluminosilicate계 유리 내부에 약 $15 \mathrm{~nm}$ 정도의 $\mathrm{LaF}_{3}$ 결정을 석출 시킨 투명 oxyfluoride 결정화 유리가 보 고되었다. ${ }^{19)}$ 이 결정화 유리는 산화물 유리의 제조상 가 지는 장점을 가지고 있으며, 활성 물질인 희토류 이온에 필요한 불화물의 환경을 가지고 있다. 이 재료의 형광특 성 및 발광수명을 분석한 결과 $1530 \mathrm{~nm}$ 발광영역의 폭 넓은 발광밴드를 가지고 있으며, $\mathrm{Er}^{3+}$ 증폭기용 $\mathrm{ZrF}_{4}-$ $\mathrm{BaF}_{2}-\mathrm{LaF}_{3}-\mathrm{AlF}_{3}-\mathrm{NaF}$ 계 유리 보다 우수한 특성을 나 타내었다. 또한 이 재료는 광효율 면에서도 $\operatorname{Pr}^{3+}$ 증폭기 용 $\mathrm{ZrF}_{4}-\mathrm{BaF}_{2}-\mathrm{LaF}_{3}-\mathrm{AlF}_{3}-\mathrm{NaF}$ 계 유리 보다 우수한 특성을 나타내었다.

\section{3 파이브 레이저(Fiber laser)}

Photonics용으로 적용되고 있는 투명 결정화 유리의 다른 용도로서 900 1400 nm의 근적외선영역을 여기
시키는 매체로서 가변 레이저가 있다. 이 소재의 폭넓 은 발광 영역은 결정에 전이금속을 첨가하는 것으로 얻 어진다. 근적외선 영역에서 폭넓은 발광 특성을 나타내 는 대표적인 결정 소재로 $\mathrm{Cr}$ 이온을 첨가한 forsterite $\mathrm{Mg}_{2} \mathrm{SiO}_{4}$ 가 있으며, 이 결정 소재를 사용하여 가변 레이 저나 펨토초 레이저가 만들어진다. $\mathrm{Mg}_{2} \mathrm{SiO}_{4}$ 의 결정구조 중 8면체 자리에 $\mathrm{Cr}^{3+}$ 이온 상태로 존재하며, 4면체 자 리에 $\mathrm{Cr}^{4+}$ 이온 상태로 존재하고 있으며, 이 $\mathrm{Cr}^{4+}$ 이온에 의해서 $1175 \mathrm{~nm}$ 를 중심으로 하는 $900 \sim 1400 \mathrm{~nm}$ 의 광범위한 발광 특성을 나타내게 된다. 투명 결정화 유리 는 단결정과 동등한 형광 특성을 나타내며, 급냉각 과 정을 통해서 파이브 상을 만드는 것이 가능하다. 최근, forsterite와 $\beta$-willemite를 기본 구조로 하는 전이금속 이 첨가된 투명 결정화 유리가 단결정의 forsterite와 $\alpha$ -willemite와 동일하게 광대역의 근적외선 발광 특성을 나타내었다. ${ }^{20)}$ 이러한 이유로 결정화 유리가 파이브 레 이저와 파이브 증폭기 등에 적용이 가능하다.

\section{6. 나노 결정화 유리}

종래의 비교적 큰 스케일을 필요로 하는 재료로부터, 나노입자를 이용한 나노디바이스에서는 극소영역에서의 나노결정 생성 및 배열 등이 중요한 기술이 된다. 유리 에서의 나노결정 생성 기술은 bottom-up 형태의 나노 프로세스의 전형적인 예이며, 광기능 뿐만 아니라 다양 한 기능 발현 가능성으로 인하여 나노 결정화유리에 대 한 기대가 높다. 결정화 유리에서 핵형성이 일어나는 온 도는 최대의 핵성장속도를 나타내는 온도보다 낮기 때 문에 일반적으로 핵성장이 일어나기 어려운 낮은 온도 에서 1차 열처리 후, 핵을 성장시키기 위하여 고온에서 2차 열처리하는 단계적 열처리 공정을 통하여 결정화 유 리를 제조한다. 일반적인 단계적 열처리 공정을 통하여 제조하는 결정화 유리의 경우 마이크론 단위의 결정이 형성되어 불투명한 결정화 유리가 만들어지며, 유리 내 부에 나노 크기의 결정을 형성 시키기는 어렵다. 그래서 나노 결정화 유리를 제작하기 위해서는 유리 전이 온도 와 결정화 온도의 중간 영역의 온도에서 2 차 열처리 공 
정을 진행 하여야 한다. 또한, 핵형성이 일어나기 쉬운 유리 조성의 설계가 아주 중요하다. 그리고 경우에 따라 서는 $\mathrm{ZrO}_{2}, \mathrm{TiO}_{2}$, 및 $\mathrm{P}_{2} \mathrm{O}_{5}$ 등 핵형성제를 첨가하여 핵형 성을 촉진시키기 위한 방법이 필요하다.

보고된 대표적인 나노 결정화유리는 Stookey에 의해 발명된 LAS계의 결정화 유리이며, 상용화 되어있는 가 장 중요한 결정화 유리이다. LAS계 결정화유리는 열팽 창계수가 그의 제로에 가깝기 때문에 기능성 재료로서 의 적용가능성이 기대되고 있다. 또한, 무알칼리 규산염 계 나노 결정화 유리 $\left(\mathrm{SiO}_{2}-\mathrm{Al}_{2} \mathrm{O}_{3}-\mathrm{MgO}-\mathrm{ZnO}-\mathrm{TiO}_{2}\right)$ 가 개발되었으며, 특히 $\mathrm{MgSiO}_{3}$ 나노 결정으로부터 형 성되는 결정화 유리는 탄성적, 기계적 성질이 개선될 뿐 만 아니라, 아주 부드러운 연마면이 형성되는 것으로 보 고되고 있다. ${ }^{21)}$ 그리고 비선형광학 유리나 광 증폭기용 의 모체 유리로 주목되고 있는 telluride계 유리에 있었 어도 투명한 나노 결정화유리가 보고되고 있다. ${ }^{22-24)}$ 유 리 내부에 나노결정을 내포한 $\mathrm{BaO}-\mathrm{Er}_{2} \mathrm{O}_{3}-\mathrm{TeO}_{2}$ 계 및 $\mathrm{K}_{2} \mathrm{O}-\mathrm{Nb}_{2} \mathrm{O}_{5}-\mathrm{GeO}_{2}$ 계 벌크 결정화 유리가 보고되었으 며, 나노 결정화 유리의 응용 범위의 확대가 기대되고 있다. ${ }^{25)}$

\section{7. 맺음말}

현재 시판되고 있는 결정화 유리는 전열조리기구용 트레이, 인덕션 탑플레이트, 및 내열식기 등의 가전기 구, 인공치아 및 인공골재 등의 생체기능성 재료, 방화 유리 등의 건축소재 등 높은 열적, 기계적 안정성이 요 구되고 있는 제품을 제작하는데 많이 사용이 되고 있다. 이러한 제품들 이외에도 결정화 유리는 반도체 · 디스플 레이, 우주항공 분야 등에 각각의 용도별로 설계되어, 저 팽창, 내화학성 등 특화된 물성을 이용한 다양한 기 능성 소재로서의 사용이 크게 확대될 것으로 기대된다.

\section{REFERENCES}

1. M. Reaumur, "The Art of Matching a New Grid of
Porcelain", Mem. Acad. Sci., Paris (1739).

2. W. Höland and G. H. Beall, "Glass-Ceramic Technology", Wiley (2012).

3. 김병호, "결정화 유리”, 민음사 (1984).

4. S. D. Stookey, "Chemical Machining of Photosensitive Glass", Ind. Eng. Chem., 45 [1] 115-18 (1953).

5. S. D. Stookey, "Catalyzed Crystallization of Glass in Theory and Practice", Ind. Eng. Chem., 51 [7] 805-08 (1959).

6. M. Ninomiya, "New Appliaction of Low Expansion Glass-Ceramics", New Glass, 20 [3] 22-28 (2005).

7. L. R. Pinckney, G. H. Beall, and T. Ono, "Development and Application of Glass-Ceramics", New Glass, 15 [3] 51-57 (2000).

8. P. E. Doherty, D. W. Lee, and R. S. Davis, "Direct Observation of the Crystallization of $\mathrm{Li}_{2} \mathrm{O}-\mathrm{Al}_{2} \mathrm{O}_{3}-\mathrm{SiO}_{2}$ Glasses Containing $\mathrm{TiO}_{2}$ ", J. Am. Ceram. Soc., 50 [2] 77-81 (1967).

9. R. L. Moore, B. S. Haynes, and A. Montoya, "Effect of the Atomic Ordering on the Stability of $\beta$-Spodumene", Inorg. Chem., 55 [13] 6426-34 (2016).

10. W. Vogel and W. Höland, "Development, Structure, Properties and Application of Glass-ceramics for Medicine", J. Non-Cryst. Sol., 123 [1-3] 349-53 (1990).

11. W. Höland, P. Wange, K. Naumann, J. Vogel, G. Carl, C. Jana, and W. Götz, "Control of Phase Formation Processes in Glass-ceramics for Medicine and Technology”, J. Non-Cryst. Sol., 129 [1-3] 152-62 (1991).

12. W. Höland, M. Frank, and V. Rheinberger, "Surface Crystallization of Leucite in Glasses", J. Non-Cryst. Sol., 180 [2-3] 292-307 (1995).

13. W. Höland, Ivovlar-Vivadent Reoprt, 3-10, December (1998).

14. M. Frank, M. Schweiger, W. Höland, and V. Rheinberger, "High-strength Translucent Sintered Glass-ceramic of Dental Application", Glastech. Ber. Glass Sci. Technol. 71C 345-49 (1998).

15. G. H. Beall, Proc. Int. Symp. Crystallization in Glass and Liquids, "Glass-ceramics for Photonic Applications", Glastech. Ber. Glass Sci. Technol., 73 C1 3-11 (2000).

16. G. H. Beall, K. Chyung, and J. E. Pierson, Proc. 
XVIII Int. Cong. Glass, Am. Ceram. Soc. CD-ROM CO6, 44-49 (1998).

17. G. H. Beall and L. R. Pinckney, "Nanophase Glassceramics", J. Am. Ceram. Soc., 82 5-16 (1999).

18. Y. Wang and J. Ohwaki, "New Transparent Vitroceramics Codoped with $\mathrm{Er}^{3+}$ and $\mathrm{Yb}^{3+}$ for Efficient Frequency Upconversion", Appl. Phys. Lett., 63 3268-70 (1993).

19. M. J. Dejneka, "Transparent Oxyfluoride Glass Ceramics", Mater. Res. Soc. Bull., 23 [11] 57-62 (1998).

20. L. R. Pinckney, Proc. Int. Symp. Crystallization in Glass and Liquids, "Transparent $\beta$-Willemite Glassceramics", Glastech. Ber. Glass Sci. Technol. 73 C1 329-32 (2000).

21. L. R. Pinckney and G. H. Beall, "Nanocrystalline Non-alkali Glass-ceramics”, J. Non-Cryst. Sol., 219

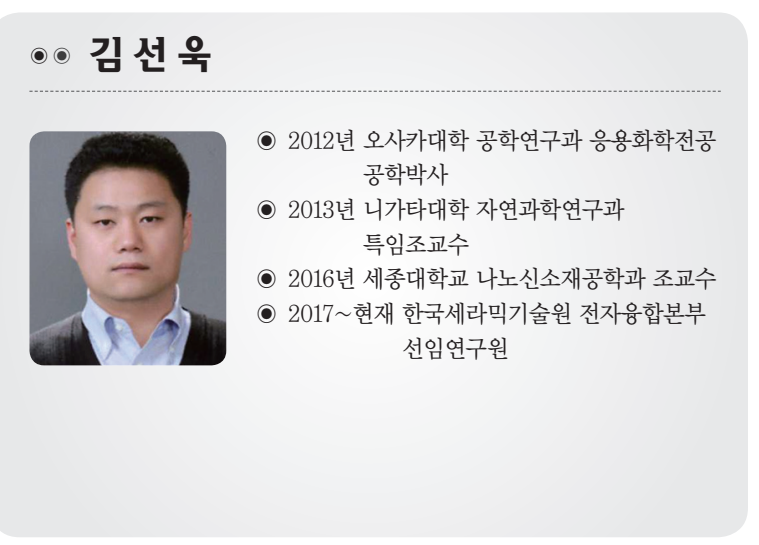

[1] 219-27 (1997).

22. K. Shioya, T. Komatsu, H. G. Kim, R. Sato, and K. Matusita, "Optical Properties of Transpatent Glassceramics in $\mathrm{K}_{2} \mathrm{O}-\mathrm{Nb}_{2} \mathrm{O}_{5}-\mathrm{TeO}_{2}$ Glasses, J. Non-Cryst. Sol., 189 [1-2] 16-24 (1995).

23. R. Sakai, Y. Benino, and T, Komatsu, "Enhanced Second Harmonic Generation at Surface in Transparent Nanocrystalline $\mathrm{TeO}_{2}$-based Glass Ceramics, Appl. Phys. Lett., 772118 (2000).

24. K. Narita, Y. Benino, T. Fujiwara, and T. Komatsu, "Vickers Nanoindentation Hardness and Deformation Energy of Transparent Erbium Tellurite Nanocrystallized Glasses", J. Non-Cryst. Sol., 316 [2-3] 407-12 (2003).

25. F. Torres, K. Narita, Y. Benino, T. Fujiwara, and T. Komatsu, "Elastic and Mechanical Properties of Transparent Nanocrystallized $\mathrm{KNbGeO}_{5}$ Glass", $J$. Appl. Phys., 945265 (2003).

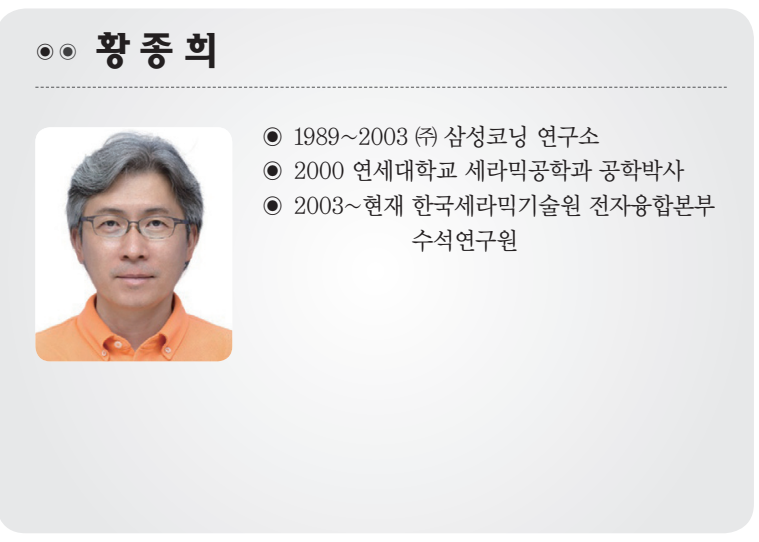


